\title{
The effect of qualitative coordination abilities on learning some attack \& defense skills and the Cognitive achievement level in foil fencing
}

Ph. D/ Ahmed Ibrahim Ahmed Azab ${ }^{(1)}$

Physical Educations Faculties always pay attention to the theoretical and practical aspect for the interest of the individual and the society. This will never achieve unless to take care of the students, and to provide them the largest portion of modern science which requires characteristics of superiority, to direct them according to their abilities and to develop them to be useful for themselves and their homeland.

Students of physical education faculties are the teachers and trainers of the future. Hence, their education process is considered one of the most important phases to reach a high level of performance where possessing the closest performance method to the technical performance is considered the basic element in superiority and improvement of performance level.

Fencing sport is among the scholar curriculums that students learn in the faculty in both its theoretical and practical aspects. It is also one of the sports that depend on the physical, skill, and tactical aspects, and is characterized by the confrontation between an individual and another; where each of them attempts to be the first to score the touch before the other. The researcher sees that coordination is one of the technical performance components of the fencing player who must have the ability to feel the distance and the time of the rival. This is related to the change of play situations and performance speed to face the speedy moves of the rival or the change of the move to another or choosing a certain moment to respond or anticipating a certain place of aim direction.

By coordination he means the athlete's ability of speedy motor performance accompanied by performance accuracy in achieving the aim

1 Assistant Professor in duels and water sports - Physical Education Faculty Menoufia University. 
along with economizing in effort. (1: 205)

Abbass Elramly \& Mohamed Ibrahim Shehata (1991) mentioned that "the coordination is the motor flowing during performing motor duties". (3: 30)

Vladimir Lyakh (2006) refer to the coordination abilities as the economic \& coordinated work possible between the muscles, the nerves, the senses, the balance, the reaction and the speedy adaptation of situations.(20: 11)

what marks the importance of the coordination abilities that when students make moves that require using more than one organ in the same time specially if these organs work in more than one direction in the same time; coordination component requires a full cooperation between the muscular \& nervous systems to be able to perform the skill in the best way specially the complicated ones which require merging skills of different kinds in one frame.

This is what Mohamed Sobhy Hassanin (2001) confirmed that juniors who lack a certain amount of coordination abilities suffer a huge difficulty in reaching the performance mechanism in addition to the unbalance between moves and its resulted skills of difficulty performance level. (8: 114)

Considering the rapid change nature of the physical and skill performance in Fencing sport where various skills of different situations and dealing with one mobile tool and players' movements in the limit of wide spaces and other limited spaces (Fencing playground), it was necessary for specialists in the field of education and training of Fencing to pay attention to the coordination abilities of Fencing.

Knowledge is considered of the important fields as it is associated with the mental operations, and the learner's ability to acquire and use information and theoretical knowledge in different levels. The knowledge also plays an important role in the educational operation; we cannot imagine an educational unit without cognitive content. (78: 10)

Also the motor performance is the outcome of cooperation and integration of 
the knowledge aspect and the motor operations. The learner when learns a certain motor skill, he often acquire theoretical knowledge connected to it. Also, acquiring these knowledge contributes in increasing the effectiveness of motor learning. (108: 19)

The researcher noticed that there are difficulties face students during performing some attack \& defense skills specially that these skills depend on the motor coordination resulted from changing body position during performance. The traditional method is considered the most common when learning Fencing skills; where the teacher uses general trainings to develop the physical, skill and psychological aspects and does not pay attention to the special coordination trainings which lead to the lack of attention to develop the special coordination abilities of Fencing despite its importance.

The researcher sees the need to make an educational program and to know its effect on the qualitative coordination abilities And some attack \& defense skills of Fencing sport to raise the physical and coordination level and to shorten the time of mastering motor skills, then to raise the technical performance and cognitive level of juniors.

\section{Research aim}

This research aims to design an educational program to develop the qualitative coordination abilities of fencing sport, then to recognize:

The effect of qualitative coordination abilities on learning some attack \& defense skills and the cognitive acquisition level in Fencing.

\section{Research Hypothesis:}

There are statistically significant differences between the experimental and control groups in the after measurements of the performance level of some attack \& defense skills (Direct thrust - Disengagement Counter Disengagement - Cut over -Simple parry- Circular parry) and the knowledge acquisition in fencing of 1 st year students of Physical Education Faculty - Menoufia University, in favor of the experimental group.

\section{Research Terms:}

\section{Coordination Abilities:}

"The cooperation between the central nervous system and the musculoskeletal 
system (muscular and skeleton) in order to perform certain aimed movements". (57: 16)

The Ability to Estimate the Situation: *

"The student's ability to estimate the changing situation of his body and other mobile things such as the foil and other people (colleagues and competitors)".

The Ability of Motor Connection:

"The student's ability to assemble the total movements of part movements and complicated movements in fencing from the individual technique skills in a way that suits the requirements of skill performance.

The Ability to exert the maximum effort:

"The player's ability to perform his movements in a coordinated way concerning power degree, time and place in a way that serves achieving the desired aim. (132: 9)

The Ability to keep the balance:

"The student's ability to keep his body in a certain position and to restore this position in case of deviation".

The Rhythm Ability:*

"The student's ability to keep the good motor performance which shows the sound and visual senses and the performance form where he feels the internal rhythm and organizes it with the internal movement in order to achieve the motor aim."

\section{The Ability of quick respond:}

"the ability to perform movements quickly after hearing signs (verbal, visual) in order to achieve a motor work as quick reaction as possible". $(127,17)$

\section{The skill performance level:}

"The degree which the athlete reaches of motor behavior resulted from the operation of acquisition and mastering the practiced activity movements so as to be performed in a way characterizes with accuracy, smooth and high degree of motivation to achieve the highest results with the least effort". (167: 4)

\section{Knowledge}

Level*

Acquisition

"The range of learner's absorption of information and knowledge of certain subject and is expressed procedurally by the degrees' difference that expresses the change in the information test of fencing skills studied in the research".

\section{Previous studies:}


1- Agnieszka (2005) (14) made a study titled "the relation between the special motor coordination abilities and the play efficiency of handball juniors". This study aimed to test the special motor coordination abilities after the annual training plan and its relation with the performance effectiveness of handball juniors. The female researcher used the experimental method on a sample of 24 female juniors. The most important results were that there are a positive relation between the motor coordination abilities and the play efficiency; which many researchers concluded but they did not introduce all the expected results. This was proven statistically and includes (the ability of motor diversity - the ability of motor adaptation). The female players also achieved very good results in the tests of special motor coordination abilities evaluation level.

2- Tarek Khalil Algamal (2008) (2) made a study titled "the effect of special coordination abilities on the skill performance level of field hockey juniors". Its aim was to recognize the special coordination abilities of hockey sport. The research used the descriptive method on a sample of (20) juniors. The most important result was that the most important special coordination abilities of the age phase (9-12) represented in the position estimation, the ability of connection, the ability to exert the suitable effort, the rhythm ability, the ability of quick respond, and the ability of adaptation to changing positions. There is a positive effect of special motor coordination abilities on some basic skills.

3- Mohammed Hamdy Abdel Hady (2009) (7) made a study titled "the effect of a training program to develop some coordination abilities on the effectiveness of spin \& Crawl swimming on the back skill". Its aim was to design a program to develop the coordination abilities and to recognize its effect on some physical variables and the spin performance time. The researcher used the experimental method on a sample of (30) swimmers. Its most important result was that the suggested program using the coordination abilities positively affected the physical 
\& skill variables of the swimmers.

4- Hadeer Saied Abdel Azeem (2010) (12) titled "the effect of using Unilateral fins on some coordination \& functional abilities of swimmers buds". Its aim was to recognize the effect of using Unilateral fins on some coordination \& functional abilities of swimmers buds. The researcher used the experimental method on a sample of (20) swimmers. Its most important result was that the most important coordination abilities in the field of swimming sport represented in the ability to estimate the position, the ability of the transitional speed, the ability of motor connection, the ability of balance and the ability of motor timing. The suggested program showed a positive effect on the physical and functional variables and the skill performance level of butterfly swimming.

The researcher used the previous studies to know how to design an educational program using some coordination abilities on learning some attack \& defense skills and the knowledge acquisition level studied in the research. He chose the suitable sample, research method, the used tools and the statistical method.

\section{Research Procedures: Research Method:}

The research used the experimental method using the experimental design of two groups; experimental \& control following the before \& after measurements as they suit the nature of the research.

\section{Research Society \& Sample:}

Research

society

included (185) of $1^{\text {st }}$ year students of Physical Education Faculty - Menoufia University, the $2^{\text {nd }}$ term of year 2011/2012. Then the researcher chose the research sample of (52) students deliberately.

Students were taken for the pilot study and the scientific interactions were performed on them. Thus, the basic research sample became (40) students divided randomly into two groups; experimental \& control each of them (20) students; table (1) shows the research sample description. 
Table (1)

Research Sample Description

\begin{tabular}{c|c|c|c|c}
\hline \hline Statement & $\begin{array}{c}\text { Research } \\
\text { Sample }\end{array}$ & $\begin{array}{c}\text { Experimental } \\
\text { Group }\end{array}$ & $\begin{array}{c}\text { Control } \\
\text { Group }\end{array}$ & Pilot \\
\hline \hline $\begin{array}{c}1^{\text {st }} \text { year } \\
\text { students }\end{array}$ & 52 & 20 & 20 & 12 \\
\hline \hline
\end{tabular}

Research Sample Coherence:

The researcher confirmed the personnel equation of basic \& pilot samples in growth rates (age height - weight), as shown in table (2).

Table (2)

The Research Sample Coherence (Experimental - Control) in the variables studied in the research

$\mathrm{N}=52$

\begin{tabular}{|c|c|c|c|c|c|c|}
\hline Variables & $\begin{array}{c}\text { Measur } \\
\text { ement } \\
\text { unit } \\
\end{array}$ & Means & $\begin{array}{l}\text { Standard } \\
\text { Deviation }\end{array}$ & Medium & $\begin{array}{c}\text { Torsion } \\
\text { coefficient }\end{array}$ & $\begin{array}{l}\text { Flattening } \\
\text { coefficient }\end{array}$ \\
\hline $\begin{array}{l}\text { Time } \\
\text { age }\end{array}$ & Year & $11 . .0 \mathrm{VV}$ & 14 & .049 &..$M Y I$ & $.7 F V$ \\
\hline $\begin{array}{c}\text { Total } \\
\text { body } \\
\text { height }\end{array}$ & $\mathrm{cm}$. & IVr. $\{A \cdot A$ & IVY.O & r.AVr & $\because \cdot 10_{-}$ & - sro- \\
\hline weight & $\mathrm{Kg}$. & $V \cdot . \varepsilon \xi Y r$ & vi & 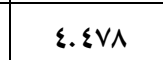 &.$r V \varepsilon_{-}$ & r. $\{\leqslant Y$ \\
\hline
\end{tabular}

Table (2) shows that torsion coefficients of research sample personnel are between $(0.321 ،-0.374)$ in the variables of (time age - height - weight) and are less that $(-3,+3)$ which indicates the coherence in these variables. 
Table (3)

(Basic) Research Sample Coherence in Growth Variables Studied in the research

$\mathrm{N} 1=\mathrm{N} 2=\mathbf{2 0}$

\begin{tabular}{|c|c|c|c|c|c|c|}
\hline Variables & $\begin{array}{l}\text { Measure } \\
\text { ment unit }\end{array}$ & Means & $\begin{array}{l}\text { Standard } \\
\text { Deviation }\end{array}$ & Medium & $\begin{array}{c}\text { Torsion } \\
\text { coefficien } \\
\mathbf{t} \\
\end{array}$ & $\begin{array}{l}\text { Flattening } \\
\text { coefficient }\end{array}$ \\
\hline Time age & Year & $14.1 \ldots$ & 11 & $.0 \leqslant 0$ & .00. & .01. \\
\hline $\begin{array}{c}\text { Total } \\
\text { body } \\
\text { height }\end{array}$ & $\mathrm{cm}$. & IVT.TVO. & IVr & r.А99 & . ro.- & - \\
\hline weight & $\mathrm{Kg}$. & v..oro. & vi & $\varepsilon .907$ & $\because$ YMA- & $1 . \wedge v 0$ \\
\hline
\end{tabular}

Table (3) shows that the torsion coefficients of research sample personnel are between $(\cdot$. YM- 6.00 .) in the variables of (time age - height - weight) and are less that $(-3,+3)$ which indicates the coherence in these variables.

\section{Data Gathering Tools \&} Equipments:

- Reference analysis, personal interview, objective notes, tests.

- Restmeter to measure height \& weight.

- Fencing playground.

First: Coordination Abilities Tests: (Appendix 3)

The researcher by making a survey study of scientific references, researchers and the previous studies determined the coordination abilities of fencing. He displayed those on
(5) experts who have no less than 10 years of experience in the field of dueling and fencing (appendix 1) to indentify the most important coordination abilities that suit the attack \& defense skills studied in the research (appendix 2).

- The ability of position estimation (the tests of go onward and backward for 14 meters).

- The ability of motor connection (the coordination tests between foot, eyes and arms).

- The ability of exerting the suitable effort (the test of going onward and stabbing for 14 meters).

- The ability of keeping the balance (the dynamic balance test). 
- The rhythm ability (test of agility during going onward and backward).

- The ability of quick respond (test of quick motor respond of the side $4^{\text {th }}$ defense and the respond by extending the arm).

Second: Evaluation Form of Skill Performance Level. (appendix 4)

Table (4)

The measurement degrees' distribution of skill performance level

\begin{tabular}{c|c|c}
\hline \hline No. & Measurement of skill performance level & degree \\
\hline \hline 1 & Direct thrust & 1. \\
\hline 2 & Disengagement & $1 \cdot$ \\
\hline 3 & Counter Disengagement & $1 \cdot$ \\
\hline 4 & Cut over & $1 \cdot$ \\
\hline & Simple parry & $1 . \square$ \\
\hline 5 & Circular parry & $1 \cdot$ \\
\hline \hline
\end{tabular}

Third: the knowledge test: (appendix 5)

The researcher used in gathering the test data specialized scientific references in the field of dueling, and the specialized studies which were made in the field of building the cognitive tests in physical education in general and in Fencing in particular in order to determine aims required to be tested
According to the experts' opinion (appendix 1), the measurement components of skill performance level were determined, in addition to identifying the measurement degree as a whole. And the degrees were distributed as shown in the next table: cognitively in the light of the following:

(Warming-up, play history, psychological aspect, play rules, basic skills). The researcher displayed the test axes on some experts in curriculums, teaching methods, dueling and sport psychology who have no less than 15 years of experience (appendix 6). As shown in table (5). 
Table (5)

The relative importance of cognitive test's axes

\begin{tabular}{|c|c|c|}
\hline Axis no. & Axes & Expert degrees \\
\hline$\square$ & Warm- up & $\% \cdot \square$ \\
\hline$r \square$ & Play history & $\%$ vo $\square$ \\
\hline$r \square$ & psychological aspect & $\%$ \%v.o. $\square$ \\
\hline$\varepsilon \square$ & play rules & $\% \ldots \square$ \\
\hline$\Delta \square$ & basic skills & $\% \ldots \square$ \\
\hline
\end{tabular}

Table (5) shows that all the axes had percentages are between $75 \%$ to $100 \%$ according to experts' opinion. 1- The primary image of the test was formed taking into consideration the test questions (comprehensiveness - clarity of expression - its suitability for research sample level scientific accuracy - measuring the aims of program's skills content - briefing - the term does not bear more than one meaning).

2- The researcher used when forming test phrases two form of phrases; the first which

\section{Table (6)}

\section{The axes of cognitive test and the phrases number of each axis}

\begin{tabular}{|c|c|c|c|c|c|}
\hline No. & Axes & $\begin{array}{c}\text { Phrases no. of } \\
\text { true or false }\end{array}$ & $\begin{array}{c}\text { Phrases no. of } \\
\text { multiple choices }\end{array}$ & Total & $\begin{array}{c}\text { Axis' } \\
\text { no. }\end{array}$ \\
\hline 1 & Warm-up &.$\square$ & $r \square$ & $\bar{\wedge} \square$ & $\overline{1}-\quad \bar{L}$ \\
\hline$r$ & Play history & $\square$ &.$\square$ & $\square$ & $1 \varepsilon-a[$ \\
\hline$\varepsilon$ & $\begin{array}{l}\text { psychological } \\
\text { aspect }\end{array}$ & $\wedge$ & $\llbracket \square$ & ir $\square$ & $r 9-10 L$ \\
\hline 0 & play rules & 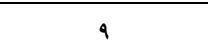 & $\varepsilon \square$ & $14 \square$ & $r q-r v L$ \\
\hline
\end{tabular}




\begin{tabular}{|c|c|c|c|c|c|}
\hline 1 & basic skills & $-\square$ & ${ }_{\wedge} \square$ & $\wedge$ & $\overline{\varepsilon v-\varepsilon \cdot L}$ \\
\hline & Total & 23 & 24 & \multicolumn{2}{|c|}{47} \\
\hline
\end{tabular}

Scientific interactions of the cognitive test:

The cognitive test was applied on the pilot study of (12) of $1^{\text {st }}$ year students and from outside the basic research sample. The researcher corrected the test and calculated the degree obtained by the student. Then, the $\mathrm{N}=12$

\begin{tabular}{|c|c|c|c|c|c|}
\hline No. & $\begin{array}{l}\text { Distinction } \\
\text { coefficient }\end{array}$ & $\begin{array}{c}\text { Difficulty } \\
\text { coefficient }\end{array}$ & No. & $\begin{array}{l}\begin{array}{l}\text { Distinction } \\
\text { coefficient }\end{array} \\
\end{array}$ & $\begin{array}{c}\text { Difficulty } \\
\text { coefficient }\end{array}$ \\
\hline 1 & $* . \Sigma T !$ & $* .0 V 7$ & rq & $* .007$ & $* . T \leqslant Y$ \\
\hline r & $* . V Y Y$ & $* .771$ & $r$. & $* .7 \wedge \varepsilon$ & $* . \leqslant 09$ \\
\hline$\mu$ & $* . .0 \Lambda Y$ & $* .0 \vee 9$ & T & $* .700$ & $* . \vee 10$ \\
\hline$\varepsilon$ & $* .011$ & $* .7 \mu r$ & Tr & *..VYT & $* .000$ \\
\hline 0 & $* .7 Y q$ & $* .711$ & r & $* .799$ & $* . . \Sigma q \mu$ \\
\hline 7 & *..AYT & $* . \leqslant 10$ & Tร & $* . \Sigma Y T$ & $* . .497$ \\
\hline V & $* . \wedge 79$ & $* . \leq T Y$ & ro & $* . \mu 71$ & $* . . \leqslant \leqslant \wedge$ \\
\hline$\Lambda$ & $* .7 \leqslant 0$ & $* . . \leqslant \Gamma \leqslant$ & $\mu$ & $* . . \leqslant .0$ & $* . .591$ \\
\hline 9 & $* . \wedge \vee \wedge$ & $* . V 7$ & TV & $* . .7 \leqslant T$ & $* . . \varepsilon O Y$ \\
\hline 1. & $* \cdot .7 \cdot \varepsilon$ & $* .777$ & rA & $* . \wedge 77$ & $* .0 V 7$ \\
\hline 11 & $* .070$ & $* . \vee \vee q \leqslant$ & rq & $* .0 \leq 9$ & $* .7 \vee 7$ \\
\hline$T r$ & $* . .597$ & $* .7 .1$ & $\varepsilon \cdot$ & $* . .590$ & $* .7199$ \\
\hline$\pi$ & $* .001$ & $* . T \cdot Y$ & $\leqslant$ & $* .099$ & $* .101$ \\
\hline $1 \varepsilon$ & $* \cdot V \cdot \varepsilon$ & $* .7 \vee 9$ & $\sum Y$ & $* .7 \wedge \mathrm{V}$ & $* . V \vee \leq$ \\
\hline 10 & $* .7 Y \leqslant$ & $* .7 \leqslant \leqslant$ & $\varepsilon r$ & $* . V Y$. & $* .7{ }^{*}$ \\
\hline 17 & $* . .0 \vee \wedge$ & $* . \vee 10$ & $\varepsilon \xi$ & $* . \Sigma V Y$ & $* .7 \vee 0$ \\
\hline IV & $* .7 .1$ & & $\leqslant 0$ & $* . .01 Y$ & $* . V I Y$ \\
\hline 11 & $* .7 \leqslant \mu$ & & $\leqslant 7$ & *. .OTY & $* . V \leqslant 1$ \\
\hline 19 & $* . V 71$ & & $\varepsilon V$ & $* .001$ & $* . V T Y$ \\
\hline$r$. & $* . \vee \cdots$ & & & & \\
\hline YI & $* .719$ & & & & \\
\hline YY & $* .070$ & & & & \\
\hline Tr & $* .7 \leqslant 1$ & & & & \\
\hline$Y \Sigma$ & $* . .001$ & & & & \\
\hline ro & $* . .7 . Y$ & & & & \\
\hline
\end{tabular}
descending according to each student's total degrees in the test. The researcher accepted the phrases' distinctive factor not less than 0.41 , where the question that get this percentage is considered good in its ability to distinguish. Table (7) shows that. degrees were organized

\section{Table (7) \\ The distinction \& difficulty factor of the cognitive test}




\begin{tabular}{c|c|l|l}
\hline$r 7$ & $* .099$ & & \\
\hline$r V$ & $* .711$ & & \\
\hline$r \wedge$ & $* .7 r 0$ & & \\
\hline \hline
\end{tabular}

Table (7) shows that the distinction \& difficulty coefficients of cognitive test axes' questions enjoy a suitable distinction power, which urged the researcher to use the test to measure the knowledge acquisition.

\section{Reliability calculation:}

\section{Table (8) \\ Reliability of cognitive test}

$\mathrm{N}=12$

\begin{tabular}{|c|c|c|c|c|c|c|}
\hline \multirow{2}{*}{ Test } & \multicolumn{2}{|c|}{$1^{\text {st }}$ application } & \multicolumn{2}{|c|}{$2^{\text {nd }}$ application } & \multirow{2}{*}{$\begin{array}{c}\text { Difference } \\
\text { between } 2 \\
\text { applications }\end{array}$} & \multirow{2}{*}{$\begin{array}{l}\text { Correlation } \\
\text { coefficient }\end{array}$} \\
\hline & $\mathbf{M}$ & $\mathbf{S} \pm$ & $\mathbf{M}$ & $\mathbf{S} \pm$ & & \\
\hline $\begin{array}{c}\text { Cognitive } \\
\text { test }\end{array}$ & $9.0 \wedge r$ & .779 & $9.91 \mathrm{~V}$ & .010 & _אז". & \\
\hline
\end{tabular}

(r) Table value at level $0.05=0.576$

Table (8) shows that this is a statistically shown correlation relation at level 0.05 between the two cognitive tests applications, which indicates that test reliability in measuring what it was put for.

\section{Table (9)}

Validity of Cognitive Test

\begin{tabular}{|c|c|c|c|c|c|}
\hline No. & $\begin{array}{c}\text { correlation } \\
\text { coefficient }\end{array}$ & No. & $\begin{array}{l}\text { correlation } \\
\text { coefficient }\end{array}$ & No. & $\begin{array}{c}\text { correlation } \\
\text { coefficient }\end{array}$ \\
\hline 1 & $* .7 \vee 9$ & 11 & $* .079$ & ro & $* . \wedge\urcorner$. \\
\hline$r$ & $* .71 \pi$ & 19 & *ๆ.Tะ. & דו & $* . \wedge 19$ \\
\hline$r$ & *.ory & $r$. & $* 7.1 . \varepsilon$ & rV & $*$ *. VOs \\
\hline$\varepsilon$ & $* . .7 \vee \wedge$ & rI & $* 0.917$ & rN & *..V77 \\
\hline 0 & $* . \wedge \varepsilon$. & rT & $* .0 \leq \wedge$ & rq & $* . \wedge .1$ \\
\hline
\end{tabular}




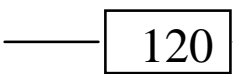

\begin{tabular}{|c|c|c|c|c|c|}
\hline No. & $\begin{array}{l}\text { correlation } \\
\text { coefficient }\end{array}$ & No. & $\begin{array}{c}\text { correlation } \\
\text { coefficient }\end{array}$ & No. & $\begin{array}{c}\text { correlation } \\
\text { coefficient }\end{array}$ \\
\hline 7 & *.ATI & rT & $* .70 \mathrm{~V}$ & $\varepsilon$. & *. VTr \\
\hline $\mathrm{V}$ & * ש & $r \varepsilon$ & *.ATo & \&1 & $* \cdot V \cdot \varepsilon$ \\
\hline$\Lambda$ & $* . \vee 00$ & ro & $* . \wedge 1$. & $\varepsilon Y$ & $*$ *. Vo. \\
\hline 9 & $* .7 \leq 0$ & $r T$ & $* .7 \vee 9$ & $\varepsilon r$ & *..人Tr \\
\hline 1. & $* . V T V$ & YV & 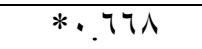 & $\varepsilon \varepsilon$ & *. Vイ \\
\hline 11 & $* . V \cdot I$ & $r \wedge$ & $* . V \cdot Y$ & $\leqslant 0$ & $* .7 \vee 9$ \\
\hline IT & $* . V Y Y$ & rq & $* . V 11$ & $\varepsilon 7$ & $* .7 \leq \Lambda$ \\
\hline $1 \pi$ & $* .7 \leq 9$ & r. & *.VTY & $\varepsilon V$ & *.VTo \\
\hline $1 \varepsilon$ & *. VOr & T & *.人ル & & \\
\hline 10 & $* . \vee \backslash \varepsilon$ & Tr & $* . \vee 79$ & & \\
\hline 17 & $* .701$ & Tr & *. . Ir人 & & \\
\hline IV & *. .VTr & Ts & *. vor & & \\
\hline
\end{tabular}

(R) Table value at level $0.05=0.576$

Table (9) shows that correlation coefficient between each phrase and the axis' total degree and between each axis and test total degree is statistically significant at level 0.05 , which indicates the test validity for what is was put for. Thus, the test in its final form is ready for application on the basic research sample as its phrases included 47 phrases, also correction key (appendix 5).

\section{Pilot study:}

The researcher performed the pilot study in the period from $18 / 2 / 2012$ to $3 / 3 / 2012$ on a sample of (12) students from research society and outside the basic sample.

\section{The Pilot Study Aim:}

- To overcome the obstacles that may face the researcher during the application of the basic study.

- To make the assistants and students understand the concepts \& nature if general \& special coordination abilities elements and the essential differences between the coordination abilities and the physical fitness elements in the development technique and the directed qualitative trainings.

- $\quad$ To determine the general aims of the program.

- To put an executive program of coordination abilities with its stages and to organize the execution of coordination abilities with its trainings according to its difficulty degree and to apply 
them on the students and to recognize the students' response according to their age stage.

- To recognize the most important \& most used tests (coordination abilities - skill performance level) that will be applied after limiting it through the result of the reference analysis, experts' opinion, periodical magazines and the search via the Internet related to research subject; Fencing.

- To confirm the suitability of the tests used in the research.

- To train assistants on how to perform the measurements of the variables studied in the research.

- To confirm the validity of the tools \& equipments used in the research.

- To calculate the
scientific interactions of the
used tests (validity -
reliability).

Results of Pilot Study:

- The obstacles that may face the researcher during the execution of the basic research experiment have been overcome.

- The coordination abilities definition has been recognized from the application aspect and also the training models of general coordination abilities for different activities and the training models of general coordination abilities of Fencing.

- The assistants'

efficiency in detecting mistakes that students may make during their application of fencing coordination abilities.

- The suitability of the used tests on research sample personnel gas been confirmed. - The validity of tools \& equipments used in the researcher has been confirmed.

- The assistants have been trained on how to perform the measurements of the variables studied in the research.

- The scientific interactions (validity reliability) of the tests studied in the research have been checked.

The Scientific Interactions of the used Tests:

First: Validity:

The researcher used the part comparison validity between the high \& low degrees in order to organize the degree descending from the higher to the lower, and to find the difference between the personnel of the pilot study sample of (12) students. 
Table (10)

The Arithmetic Means, the Standard Deviation and $(T)$ value And its significance between each of the lower \& higher spring Of the pilot study sample

$\mathrm{N}=12$

\begin{tabular}{|c|c|c|c|c|c|c|}
\hline \multirow{3}{*}{ Variables } & \multirow{2}{*}{\multicolumn{2}{|c|}{$\begin{array}{c}\begin{array}{c}\text { Lower } \\
\text { spring }\end{array} \\
\mathrm{N}=3 \\
\end{array}$}} & \multirow{2}{*}{\multicolumn{2}{|c|}{$\begin{array}{c}\begin{array}{c}\text { Higher } \\
\text { spring }\end{array} \\
\mathrm{N}=3\end{array}$}} & \multirow{3}{*}{$\begin{array}{c}\text { Difference } \\
\text { between } 2 \\
\text { averages }\end{array}$} & \multirow{3}{*}{$\begin{array}{l}(\mathrm{T}) \\
\text { test }\end{array}$} \\
\hline & & & & & & \\
\hline & $\mathrm{M}$ & $\mathrm{S} \pm$ & $\mathrm{M}$ & $\mathrm{S} \pm$ & & \\
\hline $\begin{array}{c}\text { The ability of } \\
\text { position } \\
\text { estimation }\end{array}$ & 7.7 .4 & $.01 \leqslant Y$ & A.r.r & •rVI & $1.7 \ldots-$ & $*_{V . q T V}$ \\
\hline $\begin{array}{c}\text { The ability of } \\
\text { motor } \\
\text { connection }\end{array}$ & $18.91 \mathrm{~V}$ & $\cdot r \cdot v$ & 19. rAV & .11. & $1 . \varepsilon V \cdot-$ & $*_{q .} .94$ \\
\hline $\begin{array}{l}\text { The ability to } \\
\text { exert the } \\
\text { suitable effort }\end{array}$ & rr.o.v & .rAV & יז.ד. & .019 & $r .11 r-$ & $*_{\wedge . \wedge \mu .}$ \\
\hline $\begin{array}{c}\text { The ability to } \\
\text { keep the } \\
\text { balance }\end{array}$ & rr.90. &. .091 & rA.ror & $.9 \varepsilon$. & $\varepsilon . \varepsilon \cdot r_{-}$ & $*_{V . q \cdot r}$ \\
\hline $\begin{array}{c}\text { The rhythm } \\
\text { ability }\end{array}$ & $18.90 \mathrm{~V}$ & $\ldots \varepsilon$. & $10.0 . \mathrm{V}$ &. .171 & r.A0.- & $*_{4.71 \%}$ \\
\hline $\begin{array}{l}\text { The ability of } \\
\text { quick response }\end{array}$ & I.rY. & ..ro & 1.794 & $\because 10$ & $\cdot r V r-$ & *Iq.Vrr \\
\hline
\end{tabular}

(T) Table value at morale level $(0.05)=2.776$ and free degree 4 Table (10) shows that there are statistically significant differences at morale level (0.05) between the lower \& higher spring in the tests of skill \& coordination abilities which indicates that the tests are of high validity degree and have the ability to show the differences, consequently, they measure

what it was put for and are valid to be used.

\section{Second: reliability tests:}

In order to find the reliability coefficient of the tests, the researcher applied the tests then re-test in transitional time of 3 days. The researcher used the simple correlation coefficient Liberson to find the 
correlation coefficient beteen the $1^{\text {st }} \& 2^{\text {nd }}$ applications.

\section{Table (11)}

The reliability of the coordination abilities" tests studied in the research $\mathrm{N}=12$

\begin{tabular}{|c|c|c|c|c|c|c|c|c|}
\hline \multirow[t]{2}{*}{ Variables } & \multicolumn{2}{|c|}{$\begin{array}{c}1^{\text {st }} \\
\text { application }\end{array}$} & \multicolumn{2}{|c|}{$\begin{array}{c}2^{\text {nd }} \\
\text { application }\end{array}$} & \multirow{2}{*}{$\begin{array}{c}\text { Difference } \\
\text { between } 2 \\
\text { averages }\end{array}$} & \multirow{2}{*}{$\begin{array}{c}(\mathbf{T}) \\
\text { calculated } \\
\text { value } \\
\end{array}$} & \multirow{2}{*}{$\begin{array}{c}(\mathbf{r}) \\
\text { value }\end{array}$} & \multirow{2}{*}{$\begin{array}{c}\text { Self- } \\
\text { validity }\end{array}$} \\
\hline & $\mathrm{M}$ & $\mathrm{S} \pm$ & $\mathrm{M}$ & $\mathrm{S} \pm$ & & & & \\
\hline $\begin{array}{c}\text { The ability of } \\
\text { position } \\
\text { estimation }\end{array}$ & $v . \varepsilon r \varepsilon$ & $.7 \leqslant 7$ & V.rIV & .7 .0 & $\because 111$ & 1.919 & $\because 9 \leqslant 0$ & $\cdot .9 V Y$ \\
\hline $\begin{array}{c}\text { The ability of } \\
\text { motor } \\
\text { connection }\end{array}$ & M.VFr & .094 & 11.707 & $.09 \varepsilon$ & $\because \cdot T V$ & 1.10. & $\cdot 9 \leqslant r$ & $\cdot .9 \times 1$ \\
\hline $\begin{array}{c}\text { The ability to } \\
\text { exert the } \\
\text { suitable effort }\end{array}$ & $r \varepsilon .9 V r$ & 1.rVI & Y\&.人1q & 1.111 & $\because 10 \leqslant$ & 1.940 & $\because 9 \mathrm{VV}$ & .911 \\
\hline $\begin{array}{c}\text { The ability to } \\
\text { keep the } \\
\text { balance }\end{array}$ & וצ' & $1 . \wedge 1 Y$ & r..lIV & אוער & $\cdot$ lor & 1.VV & $\because .9 \wedge \vee$ & .994 \\
\hline $\begin{array}{c}\text { The rhythm } \\
\text { ability }\end{array}$ & IE. & $1.1 \mathrm{VV}$ & rr.9r| & $1.10 \xi$ & $\cdot 1 \cdot 1$ & $1 . r 01$ & $\cdot . q V Y$ & .914 \\
\hline $\begin{array}{l}\text { The ability of } \\
\text { quick response }\end{array}$ & 1.011 & 017. & $1 . \Sigma \wedge T$ &. .17. & . . & 1.91. & $.9 \varepsilon$ & $.9 v$. \\
\hline
\end{tabular}

(r) Table value at $(0.05)=0.576$ and free degree 10

(T) Table value at $(0.05)=2.201$ and free degree 11

Table (11) shows that there is a statistically significant correlation relation between the $1^{\text {st }} \&$ the $2^{\text {nd }}$ applications, as the correlation coefficient interactions of research variables are between $(\cdot 9 \wedge \mathrm{V}-$ $\cdot 9 \leqslant \cdot)$ which indicates the tests' reliability of skill \& coordination abilities studied in the research.

The suggested educational program:

The program building steps:

- The suggested program aims to make the $1^{\text {st }}$ year students of Physical Education Faculty for males - Menoufia University for the scholar year 2011/2012 (research sample) to the highest skill level in some attack \& defense skills of fencing.

- $\quad$ To determine the content this includes the coordination trainings in the skill direction.

\section{Bases of Building the Program:}

- To determine the program aims. 
To determine the level of primary motors skills of the students.

- To determine the level of fencing coordination abilities.

The phases of coordination abilities program (the $1^{\text {st }}$, the $2^{\text {nd }}$ and the $3^{\text {rd }}$ ).

- Programs' times available for education, training and the time division according to the phases.

To determine the number of educational \& training units.

Program Tactical:

The time period of the program was determined which is (12) weeks as 1 lecture per week, according to the scholar curriculums distribution of the $1^{\text {st }}$ year of Physical education Faculty- Menoufia University.

- Lecture duration (120) min.

Bases of making \& choosing the coordination trainings:

Through analyzing the reference frame and the previous studies which the researcher viewed, it was found that when making and choosing a group of coordination trainings in order to improve the skill performance you should take into consideration the methods
\& techniques of learning and training coordination abilities, which are briefed in the following:

1) To execute the motor duties through different and varied techniques, and this is done through the following:

- Performing the motor duties.

- Changing the performance speed of motor duties.

- Performing the motor duties from different directions.

- Changing the start position and body status.

- Performing additional motor skills (before - during after) the basic movement.

- Performing motor duties where it is difficult to keep the center of body weight.

2- Executing the motor duties along with changing the used foil and performance environment as follows:

- Using playground lines and different spaces of performance.

- Changing the foil with another tool (performing motor duties by using different kinds of tools glove - tennis ball).

3- between execution change of motor duties and 
changing the outsider field such as:

- Changing the start situation (stimulation position) or body posture.

4- Executing motor duties under different pressures such as:

- $\quad$ Performing motor duties under time pressure (timing).

- $\quad$ Performing motor duties under space pressure (duel space).

- $\quad$ Performing motor duties under different rhythm pressure of dueling.

5- Diversification \& determination of information reception:

- Determining the visual vision of the student.

- Making the ability difficult to motor direct and organize by adding extra motor duties before performing the basic motor duty.

- Selecting the suitable motor duty after receiving certain visual information.

6- When performing the coordination abilities' trainings, the following should be taken into consideration:

- $\quad$ To be short, diverse and different.

To shift between easy and difficult so that there will be no quick concentration in performance.

- The in-between breaks between trainings so that the student will be calm when performing the coordination trainings, because he needs to have the good ability to concentrate so that the trainings will have a good effect on the performance,

In light of what is mentioned previously, the researcher determined a group of qualitative coordination trainings in order to improve the skill performance level of the sample studied in the research.

The content of daily training unit:

- The preliminary part (warm-up) (physical trainings in the same direction of the coordination ability) $25 \mathrm{~min}$.

- The main part (the suggested coordination skill trainings studied in the research) $90 \mathrm{~min}$.

- $\quad$ The final part (the calmdown and stretches) $5 \mathrm{~min}$.

The executive steps of the program:

The before measurement:

The before measurements were performed on Sunday 4/3/2012 using a group of coordination abilities skill tests on the $1^{\text {st }}$ 
year students of Physical Education faculty for males Menoufia University.

Executing the program:

The suggested program (appendix 7) was applied for (12) weeks in the period from $3 / 5$ to $28 / 5 / 2012$ as one lecture per week; the time of the lecture was (120) min.

The after measurement:

The after measurements were performed on Tuesday 29/5/2012 using a group of coordination abilities skill tests on the 1st year students of Physical Education faculty for males - Menoufia University.

\section{Statistical treatments:}

The researcher used the following statistical treatments using the computer statistical program SPSS, and calculated:

- $\quad$ The arithmetic means.

- $\quad$ The medium.

- The standard deviation.

- The coefficient of torsion.

- The coefficient of

flattening.

- $\quad \mathrm{Ca} 2$ value.

- T-test.

Display \& Discussion of results: 
Table (12)

Differences significance between the two after measurements of the two experimental and control groups in the coordination abilities studied in the research

$\mathrm{N} 1=\mathrm{N} 2=20$

\begin{tabular}{|c|c|c|c|c|c|c|}
\hline \multirow{2}{*}{ Variables } & \multicolumn{2}{|c|}{$\begin{array}{c}\text { Experimental } \\
\text { group }\end{array}$} & \multicolumn{2}{|c|}{ Control group } & \multirow{2}{*}{\begin{tabular}{|c|} 
Differen \\
ces \\
significa \\
nce
\end{tabular}} & \multirow{2}{*}{ (T) test } \\
\hline & $\mathrm{S} \pm$ & $\mathrm{M}$ & $\mathrm{S} \pm$ & $\mathrm{M}$ & & \\
\hline $\begin{array}{c}\text { The ability of position } \\
\text { estimation }\end{array}$ & $V . r \cdot v$ & $\cdot .0 \leqslant r$ & V.ד &. $.0 \mathrm{VI}$ & •rrYV- & $*_{\text {Y.009 }}$ \\
\hline $\begin{array}{c}\text { The ability of motor } \\
\text { connection }\end{array}$ & M. s|r & $.00 Y$ & 11.91. & 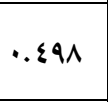 & $\cdot\{947-$ & $* \varepsilon .117$ \\
\hline $\begin{array}{l}\text { The ability to exert } \\
\text { the suitable effort }\end{array}$ & $r \leqslant .0 \leqslant \wedge$ & $\cdot . \wedge 9 \varepsilon$ & ro.1.7 & $\cdot . v \cdot 9$ & 1. ro9- & $*_{7 . \Lambda \cdot 1}$ \\
\hline $\begin{array}{c}\text { The ability to keep } \\
\text { the balance }\end{array}$ & r..l1r & 1.010 & $r V . r \cdot \varepsilon$ & $1.70 r$ & $1.191-$ & $*_{r . r V Y}$ \\
\hline The rhythm ability & 1S.YYO & $\because .0 V Y$ & $1 \varepsilon . \wedge V V$ & .9119 & $.70 Y-$ & $*_{r .011}$ \\
\hline $\begin{array}{c}\text { The ability of quick } \\
\text { response }\end{array}$ & $1 . r \wedge 9$ & •rrIr & 1.01. &.$|r|$ & $\cdot|r|-$ & $*_{Y . q V V}$ \\
\hline
\end{tabular}

(T) Table value at morale level $0.05=2.011$

Results of table (12) shows that there are statistically significant differences between the two experimental \& control groups in the after measurement in favor of the experimental group in the coordination abilities studied in the research, as (T) calculated value was bigger than its table value at morale level (0.05). The researcher sees that the coordination abilities as a group of general and fixed of control and direction operations, because they direct the performance in the first place and control it. Therefore, they are closely and mutually associated to the motor skills, as they are clearly shown in the form, method and speed of acquisition and learning of new skills and its use in the suitable way, and they are also shown in the mastering degree of skill performance required to be gained and in the exerted effort during the performance.

Hence,

using coordination abilities trainings 
during education is considered the training basis on the skill performance (technical performance) and also a development of it if these trainings were well designed depending on bases and methods of coordination abilities training, because these abilities are considered of the effective performance conditions which affect the skills' number and in the same time they are part of the skill structure that help in achieving a lot of skill performance aims in fencing. Training on the coordination abilities in the skill direction is important before and after the skill performance education; through coordination abilities the student can learn effectively and improve his skill performance and also use his motor stock in the most perfect way in order to achieve what he learnt and mastered of skills.

Moreover, rationing coordination trainings and selecting the suitable ones which the students trained on included coordination abilities which are considered the basis of skill and which participate in harmony to produce the optimal\& automatic form of the skills studied in the research that have the greatest effect on improving the performance level. The study results of Zak \& Duda (2003) (1) also confirm that when learning and training on basic skills, you must also train on coordination abilities. They also indicated that the improvement of tactical and skill performance level depends on the level of coordination abilities improvement.

These results agree with what Glasauer (3002) (15) and Agnieszka (2005) concluded that training using coordination abilities trainings led to the improvement of skill performance level. 
Table (13)

Differences significance between the averages of the two after measurements of the two experimental and control groups in Basic skills and cognitive acquisition

$\mathrm{N} 1=\mathrm{N} 2=\mathbf{2 0}$

\begin{tabular}{|c|c|c|c|c|c|c|c|}
\hline \multirow{2}{*}{\multicolumn{2}{|c|}{ Variables }} & \multicolumn{2}{|c|}{$\begin{array}{c}\text { Experimental } \\
\text { group }\end{array}$} & \multicolumn{2}{|c|}{ Control group } & \multirow{2}{*}{$\begin{array}{c}\text { Differen } \\
\text { ces } \\
\text { significa } \\
\text { nce }\end{array}$} & \multirow{2}{*}{$\begin{array}{c}(\mathbf{T}) \\
\text { value }\end{array}$} \\
\hline & & $\mathrm{S} \pm$ & M & $\mathrm{S} \pm$ & M & & \\
\hline \multirow{4}{*}{ attack } & Direct thrust & A.ro. & $\cdot .0 \wedge \mathrm{V}$ & $7 . \wedge 0$. & $1 . \cdot 19$ & $1.0 \ldots$ & $*_{V . \Sigma V Y}$ \\
\hline & $\begin{array}{c}\text { Disengagemen } \\
\mathrm{t}\end{array}$ & $\wedge .1 \ldots$ & $\cdot .00 \mathrm{r}$ & 7. Vo. & $1.17 \varepsilon$ & 1.ro. & $*_{4 .}$.01 \\
\hline & $\begin{array}{c}\text { Counter } \\
\text { Disengagemen } \\
\mathrm{t}\end{array}$ & A.r.. & $\cdot . \wedge \cdot 1$ & 7. ... & 1.99 & $1.9 \ldots$ & *A. т. \\
\hline & Cut over & ^. §०. & $\because v 09$ & 7.ro. & $.94 r$ & Y. $1 \ldots$ & $*_{1}$.. va. \\
\hline \multirow{2}{*}{$\begin{array}{c}\text { defens } \\
\mathrm{e}\end{array}$} & Simple parry & $\wedge .0 \ldots$ & $\cdot .7 \cdot V$ & $7.0 .$. & 1.01 & r.... & $*_{1} .107$ \\
\hline & Circular parry & A.r.. & $\cdot . \wedge \cdot 1$ & 7. $\leqslant 0$. & .01 & 1.10. & $* \mid r . \ldots \varepsilon$ \\
\hline \multicolumn{2}{|c|}{ Cognitive acquisition } & r..90. & $r .911$ & M.10. & r.lrr & $0 . \wedge \cdots$ & *^.r. \\
\hline
\end{tabular}

(T) Table value at morale level $(0.05)=2.011$

Results of table (13) show that there are statistical significant differences between the experimental and the control groups in the after measurement in favor of the experimental group in the skill tests and the cognitive acquisition level studied in the research where $(\mathrm{T})$ calculated values were bigger than its table value at morale level (0.05). the researcher attributes the superiority of the experimental group on the control group in the skill performance level to using the suggested educational program which helped in arousing the attention of the learner and urged him to exert his effort to learn and not to feel boring and to understand well the skills and to absorb them in a better way which contributed in improving the performance level of some attack \& defense skills in Fencing studied in the research. The program also take into consideration the 
division of the skills into small parts in light of its rational sequence in an organized and sequenced way and to associate them in a linear form, which helped the learner to form a clear image of the skill in addition to focus his attention in order to understand and learn each part easily.

The previous table also shows that there are statically significant differences between the two after measurements of the experimental and control groups in the cognitive acquisition level of some attack and defense skills in Fencing in favor of the experimental group. The researcher attributes this to the educational program using the coordination abilities which works to develop the cognitive aspect; as the person usually stores knowledge and information in his memory and when necessary he retrieves it which is known as self feedback, in this teaching method the direct and indirect information and knowledge about the used skills studied in the research are introduced to the learners. The suggested program through what it contains of suspense and diversification helps in enriching the cognitive aspect of learners related to the suggested educational program. This result agrees with what Mohamed Hassan Alawy indicated (1998) that the more the theoretical knowledge mastering and its application methods and also basic information of the teacher and the athletic trainer increased, the more he becomes able to develop and improve the learners' athletic level to the maximum limit. (130: 6)

This result also agrees with the study results of Fayza Shebl (2001) (5), Naglaa Abdel Moneim (2003) (11), Tarek Elgamal (2008) (2), Hadeer Abdel Azeem (2010) (12), and M Reigl (2003) (18) that indicated the importance of using teaching methods in increasing the cognitive acquisition of the learners. As Alfred (2001) indicated that acquiring theoretical information and knowledge contributes in the increase of the learner's effectiveness, and that the degree of learner's skill performance depends on the teacher's ability of good explanation of the skill concerning the correct position of each part of the body during 
the education process. (128: 13)

Thus, researcher hypothesis are achieved which states that "there are statically significant differences between the experimental and control groups in the after measurement of the skill performance in some attack and defense skills (direct thrust, disengagement, counter disengagement, simple parry, and circular parry) and the cognitive acquisition in Fencing of the $1^{\text {st }}$ year students of the Physical Education Faculty for males - Menoufia University in favor of the experimental group".

\section{Conclusions:}

In light of research's results and in limit of the plan and procedures of the research, we conclude the following:

1- Merging the coordination trainings with the skill trainings has achieved effectiveness in improving the skill level of research sample.

2- Coordination trainings has a positive effect in improving the tests' skill performance level of the $1^{\text {st }}$ year student of the Physical Education Faculty for males Menoufia University.

3- Developing the skill tests moves in the escalating direction as a result of the continuous training on coordination trainings.

4- Coordination trainings increase the motor stock of the students which appeared in the performance of complex tests.

5- The experimental group superiority over the control group in the performance level of some attack and defense skills and the cognitive acquisition level studied in the research.

\section{Recommendations:}

In light of research aims and results and in limit of research sample in addition to the execution of coordination trainings program in this research and recording the results, the researcher recommends the following:

1- The necessity to pay attention to learning and training the coordination trainings and to list them in the curriculums of Physical education faculties.

2- $\quad$ To apply the suggested trainings on different age stages and similar students.

3- $\quad$ To make a similar study on the rest of the athletic activities and on different samples and using more than one teaching method. 


\section{References}

First: Arabic references:

1- Abu Elela Abdel Fatah (1997): the athletic training, the physiological bases, Dar Elfekr Elaraby, Cairo.

2- Tarek Khalil Algamal (2008): the effect of special coordination trainings on the skill performance level of field hokey juniors, the $1 \mathrm{st}$ international conference of physical education, sport and health, 1st issue, Kuwait.

3- Abass Elramly and Mohamed Ibrahim Shehata (1991): fitness and health, Dar Elfekr Elaraby, Cairo.

4- Essam Eldin Abdel Khalek (2205): athletic training (theories and applications), 12th edition, Dar Elmaaref, Cairo.

5- Fayza Mohamed Shebl (2001): the effect of a suggested program using the different method on learning some volley ball skills of female students of physical education faculty in Tanta, an unpublished $\mathrm{Ph}$. D. thesis, physical education faculty, Tanta University.

6- Mohamed Hassan Alawy (1998): athletic psychology, 8 edition, Dar Elmaaref, Cairo.
7- $\quad$ Mohamed Hamdy Abdel Hady (2009): the effect of a training program to develop some coordination abilities on the effectiveness of spin skill and back crawl time swimming, an unpublished master thesis, physical education faculty for males, Mansoura University.

8- Mohamed Sobhy Hassanin (2001): measurement and correction in physical education and sport, 4th edition, part 1, Dar Elfekr Elaraby, Cairo.

9- Mohamed

Lotfy Hassanin (2006): the athletic achievement and the training work rules, an applicable vision, Elketab publishing center, Cairo.

10- Makarem Helmy Abu Herga, Mohamed Saad Zaghlol (1996): teaching methods and practical education in the field of scholar physical education, 2nd edition, Dar Hera. Elmenia.

11- Naglaa Abel Moneim Mohamed (2003): the effect of using the two methods of peers direction and multi-levels self application on some motor and cognitive variables of volley ball in the physical education lesson of secondary stage students, an unpublished $\mathrm{Ph}$. D. 
thesis, physical education faculty in Port Saied, Suez Canal University.

12- Hadeer Saied Abdel Azeem (2010): the effect of using Unilateral fins on some coordination and functional abilities of simmers buds, physical education magazine, physical education faculty for males, zagazig University, vol. 44, 83 issue, August.

\section{Second: Foreign references:}

\section{3- Alfred, B., (2001):} Problems the commands styles in physical education, the Journal of educational Research, Vol. 114, No. 40.

14- Agnieszka, Jadach, (2005): Connection between particular coordination motor abilities and game efficiency of young female handball players. www.awf.krakow.pl/jedn/gryze sps.

15- Glasauer, G., (2003): Koordinations training im Basketball. Von Ressourcen über Anforderungen $\mathrm{zu}$ Kompetenzen, Dissertation, Verlag Dr. Kovac, Hamburg. 16- Hohmann.A., Lames,M., Letzelter, M., (2002):
Einfuhrung in die Training Swissenschaft, (2.aufl)., Limpert, Wiebelsheim.

17- Mathews (1996): Measurement in physical education 5th ed., Saunders com- Pony, Philadelphia, London.

18- Reigl, M., (2003): Effects of motor games applied in lower primary physical education on the changes of coordination abilities of lower primary school children, faculty of physical education and sport sciences semmelwais university, Budapest.

19- Singer, M., (1995):

Motor Learning and Human performance and application to motor skills, Macmillan Publishing co., New York.

20- Vladimir Lyakh, (2006): The concepts and effectiveness of coordination training in sport, department of anthropocentricity, university of physical education in Krakow, Poland.

21- Zak, St., Duda, H., (2003): Level of Coordinating Ability but Efficiency of Game of Young Football Players. 